Crime, Histoire \& Sociétés / Crime, History \& Societies

Vol. 21, $n^{\circ} 2$ | 2017

L'histoire de la criminalité et de la justice pénale : propositions de recherche pour le $21^{\mathrm{e}}$ siècle

\title{
Future Research on Women and Crime
}

Manon van der Heijden

\section{(2) OpenEdition \\ Journals}

Electronic version

URL: http://journals.openedition.org/chs/1833

DOI: $10.4000 /$ chs. 1833

ISSN: 1663-4837

Publisher

Librairie Droz

\section{Printed version}

Date of publication: 31 December 2017

Number of pages: 123-133

ISSN: 1422-0857

\section{Electronic reference}

Manon van der Heijden, "Future Research on Women and Crime", Crime, Histoire \& Sociétés / Crime, History \& Societies [Online], Vol. 21, $n^{\circ} 2 \mid 2017$, Online since 19 July 2020, connection on 12 January 2021. URL: http://journals.openedition.org/chs/1833 ; DOI: https://doi.org/10.4000/chs. 1833 


\title{
Future Research on Women and Crime ${ }^{1}$
}

\author{
Manon van der Heijden
}

$\mathrm{I}$ $\mathrm{n}$ the last few decades criminologists and crime historians have made important steps in the understanding of women and crime in the past ${ }^{2}$. First, scholars have gathered data on women's contribution to crime in various parts in Europe and during different time periods. Such examinations revealed that women's involvement in crime was in various parts in Europe much higher in the period before ca. 1900 than in the modern period. There were also significant differences between towns and the countryside; women's proportion in prosecuted crime was higher in towns and cities than in rural areas. Second, criminologists and historians gained a better understanding of the influence of gender stereotypes on both women's involvement in crime and social and institutional responses. Gender stereotypes resulted in some periods in women constituting a relatively low proportion of participants in crime, and in relatively low prosecution rates of female criminality. Finally, comparative research on crime and gender has shown that women's crimes are generally similar to those committed by men: both men and women committed primarily petty offences ${ }^{3}$.

Research on women and crime has moved forward, but the topic remains underresearched when compared to scholarly work done on criminality of men in the past. Most criminologists and crime historians do not include women in their analyses of long term trends in violence and theft and the prosecution of crime ${ }^{4}$. New relevant research directions, such as the impact of migration and ethnicity on prosecution, and new perspectives, such as globalization and global comparisons, seldom take into account gender differences.

This article discusses how new directions in crime history may be relevant to the history of women and crime in the past. Migration and prosecution in relation to gender is the topic of the first part. The second part pleads for research women and crime in colonial contexts. The final paragraph briefly discusses the importance of comparative perspectives.

\section{FEMALE MIGRANTS AND THE COURTS}

Migration is the first topic that I want to address and is one that - in my view - deserves much more attention from historians working on crime and gender. Let me start with explaining why migration is important for understanding trends in

1 I would like to thank Jeannette Kamp, $\mathrm{PhD}$, for providing me an overview of the literature on migrants and crime.

2 For recent overviews: Van der Heijden (2016a); Knepper (2016, p.173-201); Schmidt and Pluskota (2013). See also: www.crimeandgender.nl

3 Beattie (1975); Walker (2003); Van der Heijden (2016b); Castan (1980); Farge (1974); Van Dijk (2006).

4 For instance: Gurr (1981); Eisner (2000). 
crime and prosecution of crime as well as the forms of crime committed by men and women. Although crime historians often pay attention to the impact of poverty on crime and the socio-economic background of those who came before the courts, their analyses rarely include differentiation in geographical origin. That is surprising, considering the substantial proportion of migrants living in European towns in the early modern period. Before c. 1850, urbanization was not the result of natural growth but rather of migration rates. Urban population grew because, attracted by economic opportunities, people moved from the countryside and other non-urban regions to the city. Migration rates varied across early modern Europe, but generally migrants made up approximately 30 per cent of the urban population ${ }^{5}$. In fast growing cities such as London, Paris and Amsterdam migration rates were even higher: sometimes the number of migrants was in excess of the number of the native population.

There are still few available statistics about the percentage of these migrants who were women, but clear indications exist that the figures were generally high. In seventeenth-century Amsterdam probably half of all migrants were women. These women had to compete on the labour and marriage market with Amsterdam-born women and their vulnerable though independent position increased their likelihood of becoming involved in crime. Various studies have shown that before 1800 the freedom of the city had a particular impact on women's criminality. J.M. Beattie was the first to show that women accounted for a much larger proportion of the total crime in the city than in rural areas, and his findings on Surrey and Sussex were confirmed by data from other regions, in Britain as well as on the continent ${ }^{6}$. Beattie did not mention the factor of migration, but his characterization of criminal women as free, independent and in employment applies particularly to early modern migrant women ${ }^{7}$. Migrant women were doubly at risk of becoming involved in crime: they not only lived relatively free and independent lives with less restrictions than rural women, without family support they were also the most at risk. Studies on migrants have shown that migrants often had much weaker social and economic networks to fall back on; their families were not around to support them financially or to assist them in times of need. The majority of female migrants belonged to the poorest strata of the urban population, and many of them adopted a survival strategy that Olwen Hufton termed an economy of makeshifts. They managed to survive through a combination of economic activities and other forms of support, such as seasonal labour, temporary work, work in the home, poor relief, help from neighbors and friends, and sometimes theft, fraud, or prostitution ${ }^{8}$.

Although there seems to be a plausible connection between female migration and female crime rates in early modern towns, little data has been gathered yet about the percentage of these migrants who turned to crime. Settlement regimes and entitlements of migrants varied throughout Europe and may have influenced the level and nature of their criminality ${ }^{9}$. The German historian B. Althammer recently suggested that the emergence of the welfare state in Europe resulted in institutions that provided women

Clark et al. (2009).

6 Beattie (1975); King (2008, p.196-226); Van der Heijden (2016b, p.17-23).

Beattie (1975, p.100-102).

Hufton (1974); Hurl-Eamon (2008); Van der Heijden (2016b, p.21-23).

$9 \quad$ Innes et al. (2013); Hitchcock (2012); Lucassen (2013). 
and children in particular with a much broader range of social facilities and support. Consequently, the category of migrant women who traditionally had turned to begging and vagrancy declined ${ }^{10}$. State formation also brought about new definitions of citizenship and vagrancy that influenced migrant status and determined the ways the accused were treated by the police and the courts ${ }^{11}$. Such changing definitions have important implications for examining the prosecution of migrants. It brings up the issue of who was considered a migrant. In early modern times all people born outside the town were considered "foreign", since citizenship was attached to a town or city, not to a state. It also implies that until c. 1800 there was no relation between the legal status of migrants and the distance they had travelled or the country in which they were born ${ }^{12}$.

The over-representation of migrants is an important issue that has received even less attention than the actual crimes committed by migrants. Were migrants over-represented amongst the accused because they were treated differently by the courts? Of course, historians are hampered by the fact that historical records not always give consistent information about ethnicity or the geographical origin of the accused. On the other hand, crime historians have not given much thought to the discriminatory patterns of courts and differences in the treatment of migrants and natives. In eighteenth-century Rotterdam 42 per cent of female suspects came from elsewhere, but it is not clear whether migrants were more likely to be prosecuted ${ }^{13}$. Their clothing, habits, and ways of speaking must have attracted attention, but there is no evidence that they were strongly over-represented among convicted criminals. In her work on migrants in seventeenth-century Amsterdam Kuijpers concludes that people from outside Amsterdam were at most slightly over-represented in crime records ${ }^{14}$.

Some work has been done on the eighteenth and nineteenth centuries. Godfrey, Lawrence and Williams devoted a chapter on immigration, ethnicity, race and crime in their textbook History \& Crime $(2008)^{15}$. They provide an overview of immigration and ethnicity in Britain since c. 1800 in order to put the involvement of immigrants and ethnic minorities in the criminal justice system in a proper context. In addition, their chapter pays attention to the role of the media in perceptions attached to migrant communities and data available on the actual patterns of migrants. Their review primarily looks at the literature on the London Old Bailey and the crime reports in London's newspapers. Although the evidence is still limited, they come to several interesting conclusions. First, there are no clear indications that black immigrants were associated with criminality during the second half of the eighteenth and the first half of the nineteenth century. Peter King combined Old Bailey data of the 1790s with other records, such as trial reports and prison records, and found that black inhabitants were not more likely to be accused of a crime than white people in London ${ }^{16}$.

\footnotetext{
$10 \quad$ Althammer (2015).

11 For the policing of migrants see: De Koster and Reinke (2016).

12 Lucassen (1997).

13 Van der Heijden (2016b, p.20).

14 Kuijpers (2005, p.310); Spierenburg (1978).

15 Godfrey et al. (2008, p.101-125).

16 Godfrey et al. (2008, p.117-118). Also: Myers (1996, p.98); King and Wood (2015).
} 
However, there was one group of immigrants that was considerably overrepresented in the London criminal statistics: the Irish. Godfrey, Lawrence and Williams link the over-presentation of Irish offenders with the types of crimes committed by them: petty criminality and public disorder. These high prosecution rates were in part the result of their actual behavior and the fact that Irish migrants were part of the lowest socio-economic categories ${ }^{17}$. They were also more likely to be prosecuted because of their social status and prejudice directed against them. As the authors conclude: "Social groups such as the Irish immigrants of the nineteenth century, and to a lesser extent the African-Caribbean communities of the 1970s lived in socially disadvantaged, geographically concentrated communities"18.

The recent study of King is the first in-depth examination of immigrant communities and the courts in eighteenth and nineteenth-century London ${ }^{19}$. King systematically comparers the place of birth of the accused, the age of each migrant group, their occupation by place of birth, the categories of committed by each migrant group, and the sentences given. His exercise includes examinations on different levels: detailed construction of court cases and a statistical analyses of the data. Whereas the microhistorical approach would indicate that the justice system had a serious tendency to discriminate against migrant minorities, the data on the prosecutions and convictions show that the majority of the migrants were not treated any differently from the native born. Although King's micro-history involves an Irish woman who underwent an unfounded accusation of homicide and was being held for nearly five month awaiting trial, his statistical analysis does not include differences between men and women. King and Wood do have some information about the accusation rate of black women in the London criminal justice system; it seemed that that there was also no overrepresentation of black women among the accused ${ }^{20}$. Kali N. Gross however, paints a less positive picture of African American women in the criminal justice system in the twentieth century. She points to the disproportionate rate of incarceration and longer prison sentences, and the fact that black women's experiences of crime and justice are still under-researched. Gross rightly concludes that "these issues continue to cry out for broader scholarly and historical treatment"21.

New insights on the treatment of migrants before c. 1900 may also encourage scholars working on women and crime. It raises questions, such as: Were female migrants treated differently by the courts than female native born? Were female migrants treated differently by the courts from their male counterparts? And to what extent did political upheaval and economic decline have impact on the prosecution rates of male and female migrants? Crime historians seem to agree that the majority of the accused migrant population generally lived similar lives and found themselves in similar socio-economic circumstances compared to accused native born. On the other hand, case studies on migrants coming before the courts do reveal that in some cases there were prejudices against outsiders. This complex mixture of equal legal treatment and discrimination may also be found in the trials against migrant women.

\footnotetext{
17 See: King (2013).

18 Godfrey et al. (2008, p.120).

19 King (2016).

20 King and Wood (2015, p.113).

21 Gross (2016).
} 
Or did women find themselves in different circumstances because they received more support by social institutions and/or they were treated more leniently by police officers and the courts than male immigrants? New research that would involve the prosecution of male and female migrants can provide answers to such questions and will deepen our understanding of the representation of migrants before the courts.

The research and insights of criminologists might be helpful in achieving this. Criminologists have been working on issues like ethnicity, immigration and prosecution for a much longer time than historians, and by doing so, they use methods and terminologies that can benefit historical research. The term crimmigration plays a key role in the debate about immigrants in the criminal justice system. The term generally refers to the intersection of criminal law and immigration, which leads to the increasing enforcement and punishment of immigrants in the criminal justice system. Although crimmigration has become a central concern in scholarly work on migration and crime, it is often examined purely or largely as a male issue. In an article in the Journal of Gender, Law \& Justice American lawyer Hartry concludes: "Women are often invisible in criminal justice and immigration discussions, and the new focus on crimmigration is no different" 22 .

Hartry pleads for the intersection of crimmigration and gender for various reasons. Firstly, she argues that women's imprisonment has increased significantly in the recent decades, both in number and proportion. Her evidence is based on the situation in the United States, but there are similar developments to be noticed in Western European countries ${ }^{23}$. Female crime rates seem to have generally risen in most parts of the Western world from the 1960s onwards. Secondly, nearly half of the immigrant population is female ${ }^{24}$. Thirdly, she argues that increasing policies against drugs and property crime particularly affect women, because they are more likely than men to be prosecuted for "drug-related or petty, nonviolent property crimes" 25 . Finally, female immigrants are more vulnerable than male immigrants, because they are generally the caregivers of children. The policy of deportation and the consequent loss of their children would particularly harm female migrants. And compared to native born women, female immigrants face more employment, race and class inequities in the criminal justice system.

The characteristics as described by Hartry are remarkably similar to the majority of women accused by the courts before c. 1900. They too were often migrants who were the caregivers of children, who had a hard time finding employment and an income, who committed petty crimes as part of their economy of makeshifts, and who were separated from their children after being banished from their town by the justice system. The question is if such characteristics can be linked to an over-representation of accused female migrants in the past. Future research that examines the intersection of crime, gender and migration may answer such a vital question.

\footnotetext{
22 Hartry (2012, p.27, citation p. 6).

23 Van der Heijden (2016a, p.260-263).

24 http://ec.europa.eu/eurostat/statistics-explained/index.php/Migration_and_migrant_population_statistics

25 Hartry (2012, p.14).
} 


\section{WOMEN AND CRIME IN COLONIAL CONTEXT}

A second important theme that deserves more attention from crime historians working on female criminality concerns migration as well, albeit in the colonial context. The last decade has seen a marked increase in scholarly interest in global approaches to criminality and the criminal justice system in colonial societies. Legal historians and anthropologists have focused on the legal pluralism in colonial cities: the complex reality of multiple justice systems and customs and ways in which governments and people made use of these different forms of criminal justice ${ }^{26}$. Such studies also improve our understanding of the extent to which women had access to courts and how they used legal plurality to defend themselves against crime of others. Barkey found that in the Ottoman Empire, legal pluralism provided Christian and Jewish women with freedom and space for the choice of legal strategies ${ }^{27}$.

Other historians have begun to explore the lives of convicts who were transported from their European homeland to the colonies. The availability of large datasets on transportation that resulted from Old Bailey sentences from the eighteenth century onward have made such research increasingly possible. The Digital Panopticon for instance, brings together genealogical, biometric and criminal justice datasets held in Britain and Australia in order to explore the impact of the different types of penal punishments on the lives of 90,000 people sentenced at The Old Bailey between 1780 and $1875^{28}$. The website Founders and Survivors: Australian life courses in historical context 1803-1920 encourages the recording and research of the men, women and children who were transported to Tasmania ${ }^{29}$. Although most of the work is still at an early stage, some studies have devoted attention to female convicts in colonial settings. In her book of 2007, Reid was the first to study the lives of those transported to Tasmania from a gender perspective. She argues that the focus of scholars on either men or women, distorted the understanding of the lives and relationships of those who were transported; convict men generally figured as violent and abusive, convict women as victims of abuse. Her analysis points to the serious impact of colonial policies on family life and relations between husbands, wives and children. In order to discipline them, colonial authorities constantly threatened convict mothers confined to the female houses of correction to separate them from their children ${ }^{30}$. A more recent study by Fleming looks at the transportation of women from Kildare to Tasmania in the mid nineteenth century, and offers information about the crimes and convictions of these women and their opportunities to start a new life. She also pays attention to the individual life stories of female convicts, who were sometimes transported at a very early age ${ }^{31}$.

Historians have also begun to look at the access to and use of justice of various ethnic groups in colonial societies. In colonial settings subordination and power played a crucial role in all relations, but maybe the most in societies where people

\footnotetext{
26 Benton (2002).

27 Bakey (2013).

28 https://www.digitalpanopticon.org/

29 http://foundersandsurvivors.org/

30 Reid (2007).

31 Flemming (2012).
} 
were legally enslaved. The logical assumption might be that "criminal" slaves were much worse off than their free white counterparts in the colonial community. In her work on black women in the American criminal justice system, Gross emphasizes that "historically black women had little access to justice and protection, particularly in the late nineteenth and early twentieth centuries" 32 . Some exploratory work has been done by Jeff Forret, who examined accusations of violence committed by slaves appearing before various courts in the eighteenth and nineteenth-century South. Most of these court cases involved violence by one slave against another, though occasionally also between slaves and free blacks ${ }^{33}$. It may be no surprise that cases of black female violence appeared far less frequently before the courts than violence committed by enslaved men. Nevertheless, Forret argues that such cases can inform historians about "the meaning of black femininity and enslaved female honor in the American South as well as the peculiar stresses that bondage placed on female slaves" 34 .

These records also tell us which violent incidents between enslaved women could lead to court trials. Remarkably, it seems that violent acts by black women living on a plantation were to a greater extent than those of enslaved men punished on the plantation where the incidence occurred. Usually, they were whipped for fighting. Furthermore, compared to white women the proportion of intra-racial homicide by bondwomen was considerably higher: in Virginia enslaved women accounted for 31 percent of all intra-racial homicides found by Forret in the records between 1796 and 1864. Like white women in the Western world in the eighteenth and nineteenth centuries, female slaves directed their violence more often at infants and children than on adults. Forret argues that violence was a means for enslaved women to control their reproduction, and thus an expression of enslaved femininity ${ }^{35}$.

Agency seems to be a key word in the studies of women in colonial context. New strands in colonial history as well as crime history have shifted the focus from the actions and policies from governments and rulers to the "agency" of those who were subject of these policies. Although "agency" can be a very helpful term, scholars have also objected to the use of "agency" for various reasons. The concept of "agency" would wrongly suggest that people in subordinate positions had power and influence, and consequently disregard the undisputedly unequal power relations between master and slave, women and men, poor and rich, and judges and accused. In the context of slave communities Walter Johnson has strongly argued against the use of the concept of "agency", labelling it as an attempt on the part of academics to be politically correct, and a mindset that rather hinders the full understanding of lived experiences of enslaved communities ${ }^{36}$. However, "agency" also means uncovering opportunities offered to and strategies employed by people who on the surface had little freedom of action. Forret does exactly this in his account of incidents of violence among slaves in the Old South. The concept of "pauper agency" has also proved helpful in the study by Tim Hitchcock and Robert Shoemaker on London criminals in the eighteenth

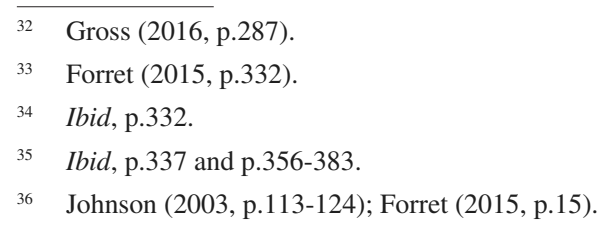


century. They found that convict men and women shaped the criminal justice system by making a choice in situations that were seemingly without alternative options. Authorities were forced to make changes in the criminal justice system, because convicts were rather sentenced to death than transported to Australia ${ }^{37}$. The notion of "agency" thus opens alternative perspectives on the lives of criminal men and women which have usually been studied from a top down perspective.

\section{COMPARATIVE PERSPECTIVE}

Finally, I want to plead for adopting comparative perspectives in the field of crime and gender. Crime historians are often reluctant in using a comparative approach, because of the complexity of comparative methods and the difficulty of comparing data and variables from different contexts. Indeed, historical sources do not represent standardized data on accused criminals: case studies each have their own particularities. Such problems can partly be overcome by concise description and explanation of the nature of different types of sources. The study of long term trends in violence has shown that long term and comparative historical perspectives have been fruitful. Without comparative studies, it would have been impossible to uncover the long term decline in violence in the Western world. Comparative approaches may also help uncover and explain trends in female crime. Furthermore, comparative methods can reveal how specific circumstances and time periods had an impact on crime and gender patterns. Comparative methods are important instruments for answering key questions, such as: which societies were tolerant towards migrants, under which circumstances, why and how did this change after c. 1900? The findings of King indicate that there were no structural discriminatory actions against migrants in the early modern criminal justice system. This raises fundamental questions about tolerance and integration in the early modern period. How then were people in early modern towns able to cope with so many different ethnic backgrounds, and why did this not result in conflicts within neighborhoods? Finally, comparative methods offer ways to measure the treatment of different groups by the courts: differences between men and women; classes; black and white; ethnic groups; and others.

\section{CONCLUSION}

In conclusion, the aim of this paper is to show the importance of including diversity as an important factor in the history of crime and gender. Firstly, examinations on migration processes and the treatment of migrants by the courts from the early modern period onwards provide a better understanding of equity in the criminal justice system. Secondly, the study of men and women in colonial societies, the impact of transporting convicts, and the treatment of enslaved people by the courts deserve more attention from crime historians. Finally, I believe that the concepts

37 Hitchcock and Shoemaker (2015). 
of "crimmigration" and "agency" and comparative methods are helpful tools in achieving these goals in future research on crime and gender.

Manon van der Heijden

Professor of Comparative Urban History

University of Leiden

The Netherlands

m.p.c.van.der.heijden@hum.leidenuniv.nl

\section{BIBLIOGRAPHY}

Althammer, B. (2015) Roaming Men, sedentary Women? The Gendering of Vagrancy Offences in nineteenth-century Europe: paper for the Conference Crime and Gender Comparative Perspectives, 1600-1900, Leiden University, The Netherlands, 27-28 November, 2015.

Barkey, K. (2013) Aspects of legal Pluralism in the Ottoman Empire, in Benton, L.A. and Ross, R.J. (Eds.), Legal Pluralism and Empires, 1500-1850, New York: New York University Press.

Beattie, J.M. (1975) The Criminality of Women in eighteenth-century England, Journal of Social History, 8, 4, p.80-116.

Benton, L. (2002) Law and colonial Cultures: legal Regimes in World History, 1400-1900, Cambridge: Cambridge University Press.

Castan, N. (1980) Les Criminels de Languedoc : les Exigences d'Ordre et les Voies du Ressentiment dans une Société pré-révolutionnaire, 1750-1790, Toulouse: Association des Publications de l'Université de Toulouse-le-Mirail.

Clark, P., Lucassen. J. and Lucassen, L. (2009) The Mobility Transition revisited, 1500-1900: what the Case of Europe can offer to Global History, Journal of Global History, 4, 3, p.347-377.

De Koster, M. and Reinke, H. (2016) Policing Minorities, in Johansen, A. and Knepper, P. (Eds.), The Oxford Handbook of the History of Crime and Criminal Justice, Oxford: Oxford University Press.

Eisner, M. (2000) Long-term Trends in Violent Crime, Crime and Justice, 30, p.83-142.

Farge, A. (1974) Délinquance et criminalité : le vol d'aliments à Paris au XVIII siècle, Paris: Plon.

Fleming, C. (2012) The Transportation of Women from Kildare to Van Diemen's Land in 1849, Dublin: Four Courts Press.

Forret, J. (2015) Slave against Slave: Plantation Violence in the Old South, Baton Rouge: Louisiana State University Press.

Godfrey, B.S., Lawrence, P. and Williams, C.A. (2008) History \& Crime, London: Sage Publications.

Gross, K.N. (2016) Black Women, Criminal Justice, and Violence, in Johansen, A. and Knepper P. (Eds.), The Oxford Handbook of the History of Crime and Criminal Justice, Oxford: Oxford University Press.

Gurr, T.R. (1981) Historical Trends in Violent Crime: a critical Review of the Evidence, Crime and Justice, 3, p.295-353. 
Hartry, A.S. (2012) Commentary: Gendering Crimmigration: the Intersection of Gender, Immigration, and the Criminal Justice System, Berkeley Journal of Gender, Law \& Justice, 27, 1, p.1-27.

Hitchcock, D. (2012) A typology of Travellers: Migration, Justice, and Vagrancy in Warwickshire, 1670-1730, Rural History, 23, 1, p.21-39.

Hitchcock, T. and Shoemaker R.B. (2015) London Lives: Poverty, Crime and the Making of a modern City, 1760-1800, Cambridge: Cambridge University Press.

Hufton, O.H. (1974) The Poor of eighteenth-century France, Oxford: Oxford University Press.

Hurl-Eamon, J. (2008) The Fiction of female Dependency and the Makeshift of Economy of Soldiers, Sailors and their Wives in eighteenth-century London, Labor History, 49, 4, p.481-501.

Innes, J., King, S. and Winter, A. (2013) Settlement and Belonging in Europe. Structures, Negotiations and Experiences, in King, S. and Winter, A. (Eds.), Migration, Settlement and Belonging in Europe, 1500-1930s, New York: Berghahn Books.

Johnson, W. (2003) On Agency, Journal of Social History, 37, p.113-124.

King, P. (2008) Crime and the Law in England, 1750-1840: Remaking Justice from the Margins, Cambridge: Cambridge University Press.

King, P. (2013) Ethnicity, Prejudice, and Justice: the Treatment of the Irish at the Old Bailey, 1750-1825, Journal of British studies, 52, 2, p.390-414.

King, P. (2016) Immigrant Communities, the Police and the Courts in late eighteenth- and early nineteenth-century London, Crime, Histoire \& Société/Crime, History \& Societies, 20, 1, p.39-68.

King, P. and Wood, J.C. (2015) Black People and the Criminal Justice System: Prejudice and Practice in later eighteenth- and early nineteenth-century London, Historical Research, 88, 239, p.100-124.

Knepper, P. (Ed.) (2016) Writing the History of Crime, London: Bloomsbury Academic.

Kuijpers, E. (2005) Migrantenstad: Immigratie en sociale Verhoudingen in 17e-eeuws Amsterdam, Hilversum: Verloren.

Lucassen, L. (1997) Eternal Vagrants? State Formation, Migration and Travelling Groups in Western Europe, 1350-1914, in Lucassen J. and Lucassen, L. (Eds.) Migration History: old Paradigms and new Perspectives, Bern: Peter Lang Publishers.

Lucassen, L. (2013) Population and Migration, in Clark, P. (Ed.), The Oxford Handbook of Cities in World History, Oxford: Oxford University Press.

Myers, N. (1996) Reconstructing the Black Past: Blacks in Britain, c. 1780-1830, London: Frank Cass.

Reid, K. (2007) Gender, Crime and Empire: Convicts, Settlers and the State in early colonial Australia, Manchester: Manchester University Press.

Schmidt A. and Pluskota, M. (2013) Gevaarlijke Vrouwen, gewelddadige Mannen? Een Review van het historisch Onderzoek naar Criminaliteit en Gender in Europese Steden, 1600-1900, Stadsgeschiedenis, 8, 1, p.60-77.

Spierenburg, P.C. (1978) Judicial violence in the Dutch Republic: Corporal Punishment, Executions and Torture in Amsterdam, 1650-1750, Amsterdam: University of Amsterdam. 
Van der Heijden, M. (2016a) Women and Crime: 1750-2000, in Johansen, A. and Knepper, P. (Eds.), The Oxford Handbook of the History of Crime and Criminal Justice, Oxford: Oxford University Press.

Van der Heijden, M. (2016b) Women and Crime in early modern Holland, Leiden/Boston: Brill.

Van Dijck, M.F. (2006) De Stad als onafhankelijke Variabele en Centrum van Moderniteit: Langetermijntrends in Stedelijke en rurale Criminaliteitspatronen in de Nederlanden, 13001800, Stadsgeschiedenis, 1, p.7-26.

Walker, G. (2003) Crime, Gender and Social Order in early modern England, Cambridge: Cambridge University Press. 